Accepted Manuscript.

Book chapter (https://doi.org/10.1007/978-3-030-13229-3_9) published in Management Science:

Foundations and Innovations (https://doi.org/10.1007/978-3-030-13229-3), Springer International

Publishing, 2 March 2019

Cite as: Oseghale, R. O, Nyuur, R.B. and Debrah, Y.A. (0) "Institutional Factors and HighPerformance Work Organisations in sub-Saharan Africa" in Machado, Carolina and Paulo, Davim (Eds.) Management Science: Foundations and Innovations, Springer.

\title{
Institutional Factors and High-Performance Work Organisations (HPWOs) in sub--Saharan Africa (SSA)
}

\author{
Dr Raphael O. Oseghale \\ Swansea University, \\ School of Management \\ Swansea, SA2 8PP, Wales, UK \\ E-mail: o.r.oseghale@swansea.ac.uk
}

Dr Richard B. Nyuur

Northumbria University

Newcastle Business School

Newcastle, NE1 8ST, UK

Email: richard.nyuur@northumbria.ac.uk

\section{Professor Yaw A. Debrah*}

Swansea University,

School of Management

Swansea, SA2 8PP, Wales, UK

E-mail: y.a.debrah@swansea.ac.uk

\section{*Corresponding author}


Accepted Manuscript.

Book chapter (https://doi.org/10.1007/978-3-030-13229-3_9) published in Management Science:

Foundations and Innovations (https://doi.org/10.1007/978-3-030-13229-3), Springer International

Publishing, 2 March 2019

\section{Institutional Factors and High-Performance Work Organisations (HPWOs) in sub-- Saharan Africa (SSA)}

This study focuses on the institutional factors that facilitate or impede the development of highperformance work organisations (HPWOs) in sub-Saharan Africa (SSA). It is based on the premise that the adoption of institutional perspective across regional hubs is pertinent in revealing and capturing the various factors influencing the creation of high-performance organisations in Africa. We argue that regulatory, normative, socio-cultural institutional factors facilitate but also impede the development of HPWOs in SSA. Building on the highperformance work practices (HPWP) model, we uncover the interactive relationship between HPWPs and the ability-motivation-opportunities (AMO) model of human resource management and how organisations can deploy them for the attainment of HPWO status.

The last decade has been particularly favourable for the emerging market of Africa in terms of economic growth. Apparently, the key drivers of this growth include a boost in the services sector, opening of new markets, technological advancements, regional economic integration (economic blocs) and infrastructural development. With the recent level of economic success, a population of more than 1 billion people [1] and several business opportunities in different flourishing sectors, the global economy is now looking at Africa for resources to sustain its development [2]. For this, Africa is beginning to capture the interest of management scholars and business leaders alike as an emerging market of new growth opportunities [2].

Despite the huge success of the last decade in Africa, most economies in the region still face some challenges. For example, some economies on the continent are largely agrarian, dominated by informal sectors and underpinned by resource-driven growth [2]. But it is possible for African countries to sustain their recent success as well as address their present challenges to become prosperous middle-income economies [3]. Indeed, some writers, have identified the role of high-performance work organisations in contributing to the development 
Accepted Manuscript.

Book chapter (https://doi.org/10.1007/978-3-030-13229-3_9) published in Management Science:

Foundations and Innovations (https://doi.org/10.1007/978-3-030-13229-3), Springer International

Publishing, 2 March 2019

of the strong economy needed to drive a stable and enduring middle-income nations [4] in Africa [3]. Unfortunately, only a few of these high-performance organisations exist in the emerging market of Africa-a development that may perhaps have inspired the Africa Academy of Management to focus its $4^{\text {th }}$ Biennial Conference on "building high-performing organisations in Africa." In this instance, more research is required to provide new insights into the factors that facilitate and/or impede the development of high-performance work organisations in Africa.

Earlier studies suggest that the weak institutions in most African countries both facilitate and impede the effectiveness of organisations operating in the region [1]. Thus institutions reflect another perspective for understanding and extending existing psychological, historical and socio-cultural theories of organisational effectiveness in Africa. It is argued that a strong institutional framework is essential for the development of Africa [5]. Although a few studies [see 1] have examined the drivers of organisational effectiveness in Africa, more work is required to develop a robust knowledge of the institutional factors that facilitate and/or impede the development of high-performance work organisations in Africa. This Chapter seeks to address this gap and propose a framework to explain how organisations can enhance their highperformance work organisation status through high-performance work practices.

This work departs from the existing literature in two ways. First, while the existing literature focuses on the entire Africa, this research specifically focus on sub-Saharan Africa. For instance, despite the tremendous diversity among most Africa countries, the extant literature [1] does not highlight any theoretically important difference among African countries in treating Africa as a single block. Treating Africa as a single block is, however, justified since their research is one of the first to examine institutional dynamics and organisational 
Accepted Manuscript.

Book chapter (https://doi.org/10.1007/978-3-030-13229-3_9) published in Management Science:

Foundations and Innovations (https://doi.org/10.1007/978-3-030-13229-3), Springer International

Publishing, 2 March 2019

effectiveness in Africa. Moreover, it makes an open call for more studies to critically examine the subject matter in the other parts of Africa to substantiate the existing knowledge and to provide new insights. Second, the research also departs from the existing literature by providing insights into how SSA firms might deploy effective high-performance work practices to overcome the strong institutional barriers in Africa and enhance their high-performance work organisation status. The question of how HPWPs may work in promoting mutual gains for firms and their employees [6] have received little attention in the HPWO literature. The existing work by Zoogah et al [1] provides insight into how organisations in Africa can develop resources and capabilities to overcome the unpredictable and complex institutional environment in Africa in order to become high-performing organisations.

Thus, the contribution of this research to the burgeoning Africa management research is twofold. First, in SSA, this research is among the first to examine the institutional factors that facilitate and/or impede the creation of high-performance work organisations in detail. As such, the paper contributes theoretically to our understanding of the factors that drive and/or impede the development of effective organisations in SSA. Second, taking the ability, motivation and opportunity (AMO) perspective which is pertinent on the mutual gain perspective (MGP) the research provides theoretical insights on how SSA firms can (in partnership with SSA governments) deploy HPWPs to facilitate their development into HPOs.

\section{High-Performance Work Organisations}

The number of high-performance organisations has increased significantly in many industrialised nations and the emerging markets of Brazil, China, India and South Africa in recent decades [7]. HPOs are important both from growth and employment point of view in that more innovative firms' with highly skilled employees are better placed to provide quality 
Accepted Manuscript.

Book chapter (https://doi.org/10.1007/978-3-030-13229-3_9) published in Management Science:

Foundations and Innovations (https://doi.org/10.1007/978-3-030-13229-3), Springer International

Publishing, 2 March 2019

services and/or products as well as more bespoke solutions for clients [4]. In HPOs, growth is measured by different organisational outcomes such as employees' equity and company efficiency [8]. Thus, several definitions and characteristics of HPOs abound in the HPO literature [see for example, 9, 10]. In general terms HPOs are defined as organisations with the capabilities to achieve sustained growth, adapt and react to changes, performing at a level higher than that of their peers [3]. HPOs also tend to have, management processes linked with overall organisational strategy, spend considerable time and resources developing its people, and focus on long-term orientation [3]. Although, none of these themes or description of HPO alone offers a detailed description of the term, they all provide important insights into the activities and outcomes of HPOs.

Of the several key themes associated with HPOs, researchers have uncovered continuous improvement and renewal of business strategies, openness and action orientation, high management quality, long-term orientation and constant improvement of workforce quality as key elements of HPOs [3]. A study of HPOs, for example, [11] found that high-performance organisations constantly update their outdated strategies by renewing them and making them unique. In other words, these companies continuously improve, simplify and align their processes, innovate new services or/and products, and create new sources of sustained competitive advantage to respond to the fast-changing needs of customers [3].

HPOs embrace an open culture. For instance, management, in this type of organisation value the opinion of their talented employees and involve them in important organisational processes [11]. Employees are allowed to spend valuable time dialoguing, learning, and exchanging knowledge in order to develop new ideas aimed at increasing their performance and that of their organisations [3]. In doing this, the employees are allowed to make mistakes and such 
Accepted Manuscript.

Book chapter (https://doi.org/10.1007/978-3-030-13229-3_9) published in Management Science:

Foundations and Innovations (https://doi.org/10.1007/978-3-030-13229-3), Springer International

Publishing, 2 March 2019

mistakes are regarded as opportunities to learn by management. The managers have great trust and belief in their employees, although, employees are made to be accountable for their actions because of the action-focused decision-making style in operation in HPOs [11]. Importantly, the managers are highly competent, open to learning, respectful, trustworthy, enthusiastic and committed [12].

In HPOs, commitment to different stakeholder groups is usually long-term. For instance, vacancies are often filled by high-potentials mainly from within (the external labour market may be used as a last resort) and employees are encouraged to take up leadership roles [3]. In view of this long term commitment, HPOs create a safe and secure environment for their employees to work and can only dismiss them as a last resort. Moreover, performance and productivity such as sales, customer satisfaction etc. are also viewed from a long-term perspective [1]. Lastly, HPOs are talent oriented. Thus management in these types of organisations identify and recruit a diverse and complementary team of employees who are highly trained to perform well and achieve extraordinary results [12].

A well-developed literature demonstrates that to attain high-performance organisation status, organisations must identify and hire employees with the right knowledge, skills, abilities and mindset. Of course, the absence of talent means that organisations may not have the right skills to design and implement strategies relevant for creating sustained competitive advantage. In their study of HPOs, Lawler et al. [13] found that the implementation of high-performance work practices is essential for the development of a high-performance work organisation. In essence, HPWPs enable active employee participation in organisational decision-making and encourage employees to utilize their firm-specific human capital in ways that will benefit their organisations [6]. As a result, employees experience a great sense of meaningfulness; become 
Accepted Manuscript.

Book chapter (https://doi.org/10.1007/978-3-030-13229-3_9) published in Management Science:

Foundations and Innovations (https://doi.org/10.1007/978-3-030-13229-3), Springer International

Publishing, 2 March 2019

more engaged and demonstrate significant commitment to work [14]. In another study of HPOs, Gould-Williams [15] found significant relationships between the implementation of high-performance work practices and desirable employees' outcome such as organisation citizenship behaviour [15]. It is however important to note that organisational activities with the potential to reduce employee trust such as employee layoff, and early retirement programs etc. are not HPWPs [16]. This is perhaps because HPWPs are practices that drive organisational performance by enhancing employees' wellbeing [16]. According to Lawler et al.[13], core HPWP practices include extensive training, worker empowerment, performance-based pay, teamwork, promotions based on merit (rather than seniority), and careful recruitment and selection of highly skilled and knowledgeable employees. Despite the several benefits associated with the use of these HPWPs, earlier studies observe that formal and informal institutional frameworks may facilitate or hinder the successful application of HPWPs and thus facilitate or hinder the development of high-performance organisations in emerging markets where the institutions are reportedly weak $[1,16]$.

\section{Institution Theory}

Organisational effectiveness largely depends on the institutional environment where an organisation operates [1]. As a result, institutional theory plays a significant role in the study of organisations [8] and occupies a central position in management research [17]. According to institutional theory, organisations pursue their business interests within institutional constraints that can potentially influence their capability to become high-performance work organisations $[1,18]$. In other words, institutions are man-made constraints that regulate human and business interactions in three main dimensions [19]. According to Scot [20], these dimensions include the regulative, normative and socio-cultural dimensions. The regulatory 
Accepted Manuscript.

Book chapter (https://doi.org/10.1007/978-3-030-13229-3_9) published in Management Science:

Foundations and Innovations (https://doi.org/10.1007/978-3-030-13229-3), Springer International

Publishing, 2 March 2019

dimension refers to rules and laws that can restrict certain type of business behaviours and promote others in a specific national environment [21]. Socio-cultural dimension refers to the common way of thinking among members of a particular society. This common way of thinking and behaviour is usually propagated through formal and informal social interactions [13]. To a large extent, such behaviour impact business activities and the way employees behave in their work places. Normative dimension refers to the beliefs and actions of important stakeholders such as employers association. Lawler et al. [13] observe that business decision makers are expected to adhere to these beliefs of what is proper and improper even though they do not completely align with the decision maker's desires and values.

Institutional theory suggests that organisations must conform to the rules and requirements of the local environment where they operate to attract some legitimacy [22]. In this instance, it is the institutional frameworks in these environments that specify the organisational structure and activities that are publicly viewed as legitimate and socially acceptable [13]. Within this framework, organisational survival does not mainly depend on the quality and quantity of organisational economic output, rather on their conformity to acceptable norms, beliefs and rules [23]. Thus organisations that comply with these formal regulatory, informal cultural and normative rules in the foreign institutional environment where they operate in are more likely to be successful. Of course, conformity to environmental requirements by firms will prompt acceptance and support in the form of clientelism (the distribution of rewards to clients) and incentives from the surrounding society where the organisations are embedded [24]. Organisations leverage on this support in the form of clientelism and incentives to create and sustain the competitive advantage they require to transform into high-performing organisation $[1]$. 
Accepted Manuscript.

Book chapter (https://doi.org/10.1007/978-3-030-13229-3_9) published in Management Science:

Foundations and Innovations (https://doi.org/10.1007/978-3-030-13229-3), Springer International

Publishing, 2 March 2019

On the other side, failure to conform to these institutional requirements and the accompanying lack of acceptance and support from an organisation's social environment can jeopardise an organisation's chances of becoming a high-performance organisation [25]. Going forward, organisations should be able to respond creatively to the various institutional forces in the environment where they operate; specifically, in institutional environments where institutional forces do not support the implementation of certain high-performance practices. Urban and Hwindingwi [26] have identified clientelism, the rule of tribe, and corruption as key informal political institutional forces that can adversely affect organisational activities. They concluded that the high levels of corruption, red tape and archaic processes put in place by government agencies discourage the growth of high-performance organisations in these emerging markets.

Earlier studies indicate that regulatory, normative and cultural "rules of the game" and their legitimacy pressures and demands on organisations requires great attention in the emerging context of Africa, as the institutional environment in this region is significantly different from those in the developed [26]. Hence building successful formal institutions and mitigating fundamental institutional voids can be intuitive for African emerging markets [AEMs] [27]. Urban and Hwindingwi [26] note that public policy makers in AEMs should improve their institutional frameworks to support organisational activities by developing a country-specific mix of business-friendly institutions and legislations. While much has been said concerning the institutional context in SSA, only limited attention has been paid to the institutional factors that impact the development of HPOs in the region [26].

\section{Institutional factors and high-performance organisations in SSA}

The extant literature on HPWPs suggests that context plays a significant role in the field of management research. In management research, contexts link observations to a set of relevant point of views, facts and events that drives research and theory development [28]. According 
Accepted Manuscript.

Book chapter (https://doi.org/10.1007/978-3-030-13229-3_9) published in Management Science:

Foundations and Innovations (https://doi.org/10.1007/978-3-030-13229-3), Springer International

Publishing, 2 March 2019

Johns [29], a differentiating feature of context is its ability to 'theoretically' explain the relational meaning of a given setting. The level of uncertainty, exogenous influences and unpredictability in SSA seems unequalled and higher than those of the developed regions [30].

As a result, the SSA context influences the effectiveness of organisations operating in the region in ways that are also different from other regions, particularly, those of the western developed context. A major area of difference is that whilst the western context is largely individualistic in orientation, in contrast, the emerging market of sub-Saharan Africa is mainly collectivist in orientation. These differences in orientation have a way of impacting the behaviour of employees and organisational outcomes in SSA firms [1]. In the SSA context, business activities are influenced by regulatory, normative and socio-cultural institutional systems as shown in Table 1.

Table 1 Formal and informal institutional factors that influence firm effectiveness in SSA

\begin{tabular}{l|l|l|l|}
$\begin{array}{l}\text { Dimensions of } \\
\text { Institutional }\end{array}$ & $\begin{array}{l}\text { Regulatory } \\
\text { systems }\end{array}$ & $\begin{array}{l}\text { Socio-cultural } \\
\text { systems }\end{array}$ \\
\hline & $\begin{array}{l}\text {-Induence on HPOs } \\
\text { incentives }\end{array}$ & $\begin{array}{l}\text {-Support from financial } \\
\text { institutions }\end{array}$ & $\begin{array}{l}\text {-Collective behaviour } \\
\text { that promotes teamwork }\end{array}$ \\
\hline Facilitators of HPOs & $\begin{array}{l}\text {-Regulations that } \\
\text { promote equal pay for } \\
\text { employees }\end{array}$ & $\begin{array}{l}\text {-Willingness to adopt 'best } \\
\text { HPW practices' from peers }\end{array}$ & $\begin{array}{l}\text { Collective behaviour that } \\
\text { promotes shared learning }\end{array}$ \\
& $\begin{array}{l}\text {-Policies that facilitate } \\
\text { reduction in tax rates }\end{array}$ & $\begin{array}{l}\text {-Union promotion of policies } \\
\text { that support employment } \\
\text { stability }\end{array}$ & \\
\hline
\end{tabular}


Accepted Manuscript.

Book chapter (https://doi.org/10.1007/978-3-030-13229-3_9) published in Management Science:

Foundations and Innovations (https://doi.org/10.1007/978-3-030-13229-3), Springer International

Publishing, 2 March 2019

\begin{tabular}{|c|c|c|c|}
\hline Inhibitors of HPOs & $\begin{array}{l}\text {-Quota system policies } \\
\text { that negatively impact } \\
\text { the recruitment and } \\
\text { selection of highly } \\
\text { skilled individuals } \\
\text {-Local content policies } \\
\text { that negatively impact } \\
\text { the sourcing of human } \\
\text { resources }\end{array}$ & $\begin{array}{l}\text {-Union activities that can } \\
\text { impede the adoption of } \\
\text { performance related pay } \\
\text {-Union activities that can } \\
\text { impede the adoption of } \\
\text { extensive use of performance } \\
\text { management systems } \\
\text {-Financial institution bias } \\
\text { (clientelism) } \\
\text {-Union activities that can } \\
\text { impede the adoption of } \\
\text { merit/performance related } \\
\text { promotions }\end{array}$ & $\begin{array}{l}\text {-Nepotism and tribalism } \\
\text { which hinders effective } \\
\text { recruitment and selection } \\
\text { of highly skilled } \\
\text { workforce } \\
\text {-Collective ideologies } \\
\text { that do not support the } \\
\text { extensive use of } \\
\text { performance } \\
\text { management systems } \\
\text {-Engagement with } \\
\text { traditional activities at a } \\
\text { cost to Organizaions }\end{array}$ \\
\hline
\end{tabular}

Source: compiled from Adams et al. (2015) and Zoogah et al. (2015)

Few studies on African institutional environments have examined political regulations, normative and socio-cultural institutional structures [see 26, 1]. From these studies, it is anticipated that the adoption of institutional perspectives across regional hubs is apt in revealing and capturing the various factors influencing the development of high-performance organisations [26]. We proceed to discuss the institutional factors that facilitate but also impede the development of HPOs in SSA.

Institutional factors that facilitate HPOs in SSA

\section{Normative institutional factors}

Formal institutions such as banking institutions, and exchange commissions' incentivize and regulate investments, business transactions and exchanges. In SSA, these institutions are usually legalised, although, some may be weak when compared to institutions in the developed western contexts [1]. Obviously, strong financial institutions influence the development of HPOs by providing the needed funds for businesses to invest in order to enhance productivity 
Accepted Manuscript.

Book chapter (https://doi.org/10.1007/978-3-030-13229-3_9) published in Management Science:

Foundations and Innovations (https://doi.org/10.1007/978-3-030-13229-3), Springer International

Publishing, 2 March 2019

[31]. By deploying the funds received and other organisational resources to good use, SSA organisations can transform into HPOs. In Nigeria, for example, credible organisations continue to benefit from the fairly efficient financial institutions as they provide these organisations with the funds they need to undertake profitable investments at affordable interest rates [26].

A second normative institutional force that can impact organisational effectiveness is labour union. In most SSA countries, employee unions promote policies such as egalitarian compensation practices etc. that can support employment stability [13, 32]. Employment stability, in turn, enhances employees' commitment which has the potentials to positively reinforce performance and thus high-performance work organisations. In this instance, performance and HPO status is moderated by employee human capital accumulated over a long period of employment with the company. In a recent study, for example, Jin et al. [33] found that employees acquire more firm-specific human capital that can increase their ability to perform in employment with an organisation over time.

\section{Regulatory institutional factors}

At the regulatory level, traditional political institutions establish legislations to regulate the operation of businesses. In some SSA countries such as Nigeria, the promotion of equal pay legislation [1], legislations facilitating the reduction of taxes and legislations providing training incentives to organisations, for example, facilitates the development of HPOs. First, providing the opportunity for all employees to earn equal pay in view of their capabilities and performance can help organisations secure the commitment of their employees. Apparently, employees' commitment moderated by job satisfaction can positively impact performance and thus help transform these organisations into HPOs. 
Accepted Manuscript.

Book chapter (https://doi.org/10.1007/978-3-030-13229-3_9) published in Management Science:

Foundations and Innovations (https://doi.org/10.1007/978-3-030-13229-3), Springer International

Publishing, 2 March 2019

The second regulatory factor that can drive HPOs is tax reduction. Tax reductions may prompt organisations into channelling money recovered from such reductions into profitable projects that can transform a firm into HPO. For instance, money realised from tax reductions can be used for human capital development projects in order to drive the human capital base of the company. Debrah et al. [34] observe that SSA firms can become highly effective with a pool of employees with the right human capital and motivation relevant for innovation. Finally, policies that provide training incentive for organisations in SSA countries also facilitate the development of HPOs. Government provision of training incentives can encourage organisations to provide training for their employees as part of training cost will be taken care of by the state. Specifically, training and development of employees will help develop the relevant workforce that firms require to make the right decisions, innovate, enhance performance and thus productivity [34] to become HPOs.

\section{Socio-cultural institutional factors}

Traditional socio-cultural institutions comprise of both the cultural and social norms in existence in SSA countries [35]. At another level, socio-cultural forces include the cultural rule of the game such as nepotism and tribalism that creates shared expectations about business patronage. Tribalism is the tendency for managers to favour people from their own ethnic groups or tribes during recruitment, selection, promotion, compensation and dismissal [30]. On the other hand, nepotism refers to a network of support among groups connected by blood, kin, community and/or religion [36]. Surprisingly, both nepotism and tribalism facilitates the teamwork required to drive performance in firms [37] and thus HPO in developing contexts. Of course, performance and HPO status will be moderated by shared learning among members of the network of support. Success, however, is dependent on two principles. First, is the firm's 
Accepted Manuscript.

Book chapter (https://doi.org/10.1007/978-3-030-13229-3_9) published in Management Science:

Foundations and Innovations (https://doi.org/10.1007/978-3-030-13229-3), Springer International

Publishing, 2 March 2019

ability to develop relevant human resource policies to acquire the best of both nepotism and tribalism [37]. For example, SSA firms can develop human resource policies that will allow managers to recommend one of their family members or friends for employment on attaining a certain standard. Second, is the firm's ability to develop human resource practices with inbuilt advantages for all employees [38]. Perhaps, this will help address any negative employee behaviour that may result from nepotism and tribalism.

Another interesting socio-cultural force in sub-Saharan Africa is the 'Ubuntu'. The word 'Ubuntu' literarily means "I am who I am through others" [39]. Although this concept originated from Zulu, it is widely used in the continent [39]. 'Ubuntu' is a strong form of collectivism which helps to integrate members of a community into a strong and cohesive ingroup [39]. In SSA, members of in-groups share resources and support each other in exchange for unquestionable loyalty, care and respect that ensure high-quality community life [1]. 'Ubuntu' create networks of social obligations that link managers to their extended families, tribes and ethnic groups. This lays out the foundation for organisational relationships with potentials to develop the teamwork needed to gain sustained competitive advantage [40] and drive HPOs [1]. Moreover, collectivism in the form of 'Ubuntu' can foster the development of HPOs through shared learning and transfer of knowledge among employees. For example, past studies have shown that managers in collectivist societies support their under-performing colleagues (who were meant for dismissal after employee evaluation) through mentoring programmes to acquire the relevant competencies required to perform well [39].

\section{Institutional factors that impede HPOs in SSA}

Normative institutional factors 
Accepted Manuscript.

Book chapter (https://doi.org/10.1007/978-3-030-13229-3_9) published in Management Science:

Foundations and Innovations (https://doi.org/10.1007/978-3-030-13229-3), Springer International

Publishing, 2 March 2019

A number of normative institutional factors also impede the development of HPOs in SSA. In this regard, union activities in SSA could impede the development of HPOs. A union presence might, for instance, be indicative of a greater likelihood of conflict for organisations seeking to pursue HPWS implementation, thus precluding or undermining effective HPWS implementation. For example, unions in many SSA emerging markets are often suspicious of merit-based employment system (which is the result of an effective performance management system) but support employment practices that allocate opportunities and rewards based on seniority. It is our opinion that, although, seniority-based promotion and pay may promote equity; it has the potential to impede the development of high-performance organisations as highly skilled employees may not be willing to improve performance since promotions and pay are based on seniority and not performance. Existing studies suggest that by rewarding performance with promotions and increment in pay, organisations motivate as well as secure the commitment of highly skilled employees [41] and thus create the advantage to transform into HPO. To strike a balance in this type of environment, SSA firms supplement seniority based pay with performance related pay with potential to drive employees' performance.

As expected, weak formal institutions such as banking institutions also impede the development of HPOs in SSA. Indeed despite the far reaching reforms in the financial sector of many SSA countries including Nigeria, Ghana, and Tanzanian, some challenges still remain. Weak financial institutions in some of these countries are usually unable to provide the funds that organisations need to invest and improve productivity [42]. In some cases, these weak financial institutions provide funds to organsations at very high interest rates that can stall profit maximisation. With high interests rates or a lack of funding to make the right investments, SSA firms may not be able to make the relevant investments required to drive HPOs. Thus we conclude that the weak financial institutions in some of these SSA countries [31] also impede 
Accepted Manuscript.

Book chapter (https://doi.org/10.1007/978-3-030-13229-3_9) published in Management Science:

Foundations and Innovations (https://doi.org/10.1007/978-3-030-13229-3), Springer International

Publishing, 2 March 2019

the development of HPOs. In view of this, Adams et al. [31], concluded that the relationship between the private sector and the financial systems in sub-Saharan Africa has not been effectively reinforced.

\section{Regulatory institutional factors}

Apparently, legislations can also impede the development of HPOs. In SSA countries, legislations that promote corruption as well as coerce organisations to abide by legal restrictions that are sometimes not conducive to the efficient implementation of HPWPs in firms impede the development of HPOs [43]. A notable regulation that indirectly impedes the development HPOs is the workforce localisation policies in many SSA countries such as Nigeria. In countries where such policies are in operation, organisations are required by law to hire a percentage of locals during recruitment [44]. Workforce localization policies are good in that they seek to promote the employment and development of local talent but the case remains that the existing shortage of talent in the SSA region [34] undermines the effectiveness of such policies. Of course, given the poor state of human capital in many SSA countries, organisations may not be able to acquire the best talent needed to create the sustained competitive advantage required to transform into HPOs. Thus, according Harry [45] private sector responses to localization policies have usually been that of resistance and when pushed hard by the government they undertake small-scale employment programs. Al Qudsi [46] reiterates this view when he pointed out that some employers find localization policies a burden and that most of them have resorted to the use of ghost workers through creating employment on paper just to wade off sanctions.

Quota system in many SSA countries can also impede the development of HPOs. In multiethnic societies, such regulation requires organisations to hire a number of applicants from 
Accepted Manuscript.

Book chapter (https://doi.org/10.1007/978-3-030-13229-3_9) published in Management Science:

Foundations and Innovations (https://doi.org/10.1007/978-3-030-13229-3), Springer International

Publishing, 2 March 2019

every section of the society during recruitments [46]. In Nigeria, for example, government regulations expect large organisations to hire job candidates from the 6 geopolitical zones in the country irrespective of whether they can get the best from all zones during recruitment [47]. In a recent study, Adisa, Osabutey, Gbadamosi and Mordi [48] found that quota system policies adversely impacted recruitment and selection in Nigeria. While quota system is a good practice in that it provides equity and fairness in a highly diverse society like Nigeria, it defies the merit principle (i.e. an instance where companies hire the best available talent wherever they are available) and as such can impede the creation of HPOs [59]. Of course, organisations cannot create competitive advantage and transform into HPOs without the needed talent. In this respect, organisations and governments in these SSA countries should embark on a massive human capital development projects to address the challenges associated with attracting quality job candidates if localization policies and quota system are to operate effectively and foster the development of HPOs.

Going forward, informal political institutions such as clientelism, rule of the tribe and corruption also affect the smooth operation of companies and thus the development of HPOs [50]. In Ghana and Nigeria, for example, chiefs and their council members wield great influence over economic, social and cultural issues [51]. For example, this traditional political pressure influences organisational activities through mandatory cultural practices [52]. Businesses are pressured into honouring festivals and other traditional celebration by closing up their business ventures-an act that hinders productivity [1] through absenteeism.

Additionally, firms operating in SSA often have to grapple with unfriendly legislative requirements [43]. In response and to avoid these harsh legislative requirements, some organisations offer bribe to government enforcers [50]. Indeed, Chironga, Leke, Lund and Van 
Accepted Manuscript.

Book chapter (https://doi.org/10.1007/978-3-030-13229-3_9) published in Management Science:

Foundations and Innovations (https://doi.org/10.1007/978-3-030-13229-3), Springer International

Publishing, 2 March 2019

Wamelen [53] found that some organisations obtain contracts, acquire resources and accomplish goals through corrupt practices and the accompanying clientelism. In the short run, these organisations get undue advantage when they offer inducement to people in positions of authority. However, Zhou and Peng [50] found that such practices negatively impact profit maximization and can stall the development of HPOs. Of course, corrupt practices and clientelism hinder the competition that is supposed to drive organisations toward the development of capabilities that can stimulate the development of the competitive advantage relevant for creating HPOs.

\section{Socio-cultural institutional factors}

Notably, socio-cultural force such as societal norms can also hinder the development of HPOs. Indeed, societal norms regulate the social activities of individuals, groups and organisations in a society. Norm refers to accepted standard or way of doing things that most people in a society agree with [35]. With more than 1,000 ethnic groups, Africa (including the SSA) has more ethnic groups than any other continent around the world [54]. In SSA, ethnic beliefs about work derive from traditional practices and this differs from European work structures [55]. Sociocultural forces such as days of work and non-work such as holidays and days of festivals affect organisational productivity through absenteeism and turnover [56].

Other socio-cultural factors that can also impede the development of HPOs include tribalism and nepotism. Unsurprisingly, tribalism often lead to organisational ineffectiveness [55] in that it promotes the hiring and retention of mediocre at the expense of highly talented people with potentials to drive company success [37]. In the case of nepotism, senior managers offer support to friends and/or family members during recruitment, training, promotions, compensation and retention. Like tribalism, nepotism has been linked with poor firm 
Accepted Manuscript.

Book chapter (https://doi.org/10.1007/978-3-030-13229-3_9) published in Management Science:

Foundations and Innovations (https://doi.org/10.1007/978-3-030-13229-3), Springer International

Publishing, 2 March 2019

performance [37] in that managers also use non-objective measures in the recruitment, promotion and retention of employees [57]. Of course, inefficiencies result from running the business with incompetent hands [37]. Another problem is that nepotism may also result to negative employee attitude on the part of the other employees who are not members of this network of support [37]. We aver that negative employee attitude will, in turn, stall productivity and thus high performance organisation. In sum, both tribalism and nepotism undermines efficiency, performance and productivity [1] in SSA firms as well as hinder the firms' ability to transform into HPOs.

Additionally, collectivist behaviours that can impede the extensive use of HPW practices such as performance management systems could hinder the development of HPOs. Earlier studies suggest that managers from collectivist societies are often reluctant to provide critical feedback to subordinates after performance assessment exercise as well as use the outcome of the evaluation process to lay-off employees [13], particularly, those classified as underperformers. Such practice could drive the retention of redundant workers who will spoil things for the companies and hinder progression into HPO status.

Interestingly, the absence of these key institutions can also facilitate or impede the development of HPOs in sub-Saharan Africa. According to Rottig [24], institutional voids-the lack or underdevelopment of certain institutions is one of the key characteristics of emerging markets, specifically, the SSA region. In most SSA countries, certain institutions such as judicial institutions, business intermediaries etc. are either absent or underdeveloped [58]. Obviously, the absence of these institutions often results to market failures in SSA [59]. For example, businesses may not be able to make important decisions when necessary due to the lack of relevant information brought about by the absence of key business intermediaries. Moreover, 
Accepted Manuscript.

Book chapter (https://doi.org/10.1007/978-3-030-13229-3_9) published in Management Science:

Foundations and Innovations (https://doi.org/10.1007/978-3-030-13229-3), Springer International

Publishing, 2 March 2019

inefficient judicial systems may be incapable of enforcing contracts in a reliable way. Hence the absence of intermediary institutions such as audit committees, aggregators, distributors makes it more costly for SSA firms to acquire inputs such as technology, finance and talent [58]. Overall, this might underpins the poor performance of firms operating in SSA and hinder their potentials for HPOs [1]. This is usually the case because an institutional void exposes organisations to risks and uncertainties that constitute into higher cost of doing business [24]. It is however, important to note that firms that can deploy organisational resources to respond creatively will develop the relevant advantage required to transform into high-performance organisation [59].

In view of the above discussion, it is increasingly important to build a strong platform for the development of high-performance work organisations in SSA in particular and Africa in general. According to Adams et al. [31], the concept of building effective institutions has been a key component of development in SSA, but the strategies required to build these institutions have eluded the region. In sum, there is a great upheaval sweeping the SSA region and the sort of institutional frameworks in the region is liable to be dumped, paving way for the emergence of a new human resource management style. In the next section, the authors provide insights into how SSA firms can collaborate with governments in the region to drive HPOs through HPWPs.

\section{Harnessing HPWPs in sub-Saharan Africa to facilitate HPOs}

The important role of HPWPs and highly skilled employees in facilitating the development of HPOs occupies a center-stage in the high-performance organisation literature [60, 6]. Drawing on the literature by Ashton and Sung [16] we suggest that SSA firms (in collaboration with governments) can deploy HPWPs for the development of HPO status. We note that HPWPs enhance employees' human capital as well as encourage positive employee attitude [6]. HPO 
Accepted Manuscript.

Book chapter (https://doi.org/10.1007/978-3-030-13229-3_9) published in Management Science:

Foundations and Innovations (https://doi.org/10.1007/978-3-030-13229-3), Springer International

Publishing, 2 March 2019

is then developed through firm innovation and increased productivity moderated by employee human capital and positive attitude/commitment [15].

The HPWPs framework combines key management practices for developing employees' abilities and work-related competencies [61]. The main difference between traditional controlbased HRM and HPWPs is the emphasis on firm employees as the main source of organisational value [6]. Taking an AMO perspective of HPWPs which is pertinent to the mutual gain perspective of HPWPs - practices that reinforces firm performance through their positive effects on employee human capital, wellbeing and attitude, SSA firms can deploy skills enhancing practices such as comprehensive recruitment, rigorous selection and extensive training to acquire and develop employees' human capital. AMO model argue that for firms to reinforce positive employee attitude and drive performance they need to work on employees abilities, motivation and opportunities by deploying a set of HPWPs effectively [62]. Prior research has shown that skills enhancing HR practices are strongly related to human capital development $[63,60]$. We note that skills development is particularly important in the emerging context of Africa where there is a reported shortage of highly skilled employees which SSA firms need to create sustained competitive advantage [34].

Furthermore, to strengthen skills development efforts SSA firms will need to motivate and create opportunities for trained employees to perform well. We note that simply developing the human capital of employees alone cannot and will not facilitate the development of HPWOs. To drive organisation performance and thus HPO status, SSA firms should implement motivation enhancing HR practices to enhance employee motivation. Typical strategies include competitive compensation, employee involvement, career development, incentives, promotion and job security etc. to elicit workplace behaviour, commitment and performance among 
Accepted Manuscript.

Book chapter (https://doi.org/10.1007/978-3-030-13229-3_9) published in Management Science:

Foundations and Innovations (https://doi.org/10.1007/978-3-030-13229-3), Springer International

Publishing, 2 March 2019

employees $[60,6]$. Specifically, employees who perceive firm action towards them as beneficial may feel obligated to reciprocate such gesture by working hard to add-value to the organisation [60]. Existing studies by Gould-Williams [15] and Sun, Aree and Law [61] found significant links between implementing motivation enhancing HR practices and desirable employees' outcomes such as job satisfaction, organisation citizenship behaviour, employee commitment and performance.

Extensive training and motivation without adequate opportunities for employees to make use of their skills as well as demonstrate commitment may not add value to the firm and thus cannot enhance firm HPO status. To enhance HPO status opportunity enhancing HR practices should be designed and deployed to propel employees to exercise their commitment as well as deploy skills to achieve organisational goals [60]. More specifically, employees' capabilities and knowledge must be put into full use by the firm to impact performance [34] and drive HPO status. This argument is consistent with the works of Gong, Law, and Xin [64] and Huselid [63] who found that deploying systems of HR practices to enhance employee human capital, motivation and opportunities is associated with positive organisational outcomes such as greater commitment, lower turnover, higher productivity, better service performance and financial performance. Thus employers are more likely to generate more positive employee attitude and organisational success when the AMO elements underpin their human resource management structure [65] in SSA.

SSA governments can also facilitate skills development on both demand and supply sides to support the development of HPOs [16]. On the demand side, the government needs to encourage the adoption of high-performance work practices such as workplace training and skills development programs in both public and private organisations [16]. This can be 
Accepted Manuscript.

Book chapter (https://doi.org/10.1007/978-3-030-13229-3_9) published in Management Science:

Foundations and Innovations (https://doi.org/10.1007/978-3-030-13229-3), Springer International

Publishing, 2 March 2019

achieved by strengthening existing policies and schemes (such as industrial training fund in Nigeria) that support workplace learning and quality training in firms. A significant number of existing national policies and schemes in some SSA countries such as Nigeria, Zambia etc. do not have the capacity to facilitate workplace learning and skills development in these countries due to poor implementation plan. To address this trend policies and schemes that support workplace learning and skills development should be developed in SSA countries were such policies and programmes are currently not in operation [34]. Government in the various SSA countries should not only develop these policies and schemes but must also develop policies to ensure the delivery of quality training. In other words, the government should be more involved both in the design and the implementation of these workplace learning programs.

On the supply side, SSA governments should work on their labour market institutions to enhance the flow of skills appropriate for the facilitation of high-performance organisations [16]. This can be achieved directly by introducing the transmission of such skills through college/university curriculum [16] as well as providing more funding for the development of higher education in this region [34]. In a recent study, Yeung [57] found that through government support and increased spending on higher education, Singapore has been able to develop the relevant talent required to drive economic growth. The extant literature suggests that a large part of what universities and colleges in SSA teach is mostly theory-based which is why some graduates in this part of the world lack certain soft and technical competencies [66].

\section{Discussion}

The study sought to identify the institutional factors that facilitate or impede the development of high-performance work organisations in sub-Saharan Africa and to suggest how organisations operating in the region in partnership with government can facilitate the 
Accepted Manuscript.

Book chapter (https://doi.org/10.1007/978-3-030-13229-3_9) published in Management Science:

Foundations and Innovations (https://doi.org/10.1007/978-3-030-13229-3), Springer International

Publishing, 2 March 2019

development of HPWOs by leveraging on HPWPs. In so doing, we advance the literature that explain the factors that hinder the development of effective organisations and how these organisations can develop the capabilities required to become high-performance organisations.

The study demonstrated multiple accomplishments in enhancing our understanding of the subject area. As the study has demonstrated, only a handful of studies have explored factors that facilitate or impede organisational effectiveness.

Going forward, the present study suggests that institutional forces facilitate but also impede the development of high-performance work organisations in SSA countries. In line with the extant literature by Ogbonnaya et al [6], by implementing mutual HPWPs SSA firms can develop the skills and employee attitude required to enhance performance and transform into HPO. Overall, in implementing the mutual HPWP perspective; SSA firms can address institutional resistance (i.e. employee/union resistance) to the use of organisational practices with negative employee outcomes when used wrongly, support workforce localisation programs through massive skills development, address the challenges associated with nepotism and gain legitimacy required to transform into HPO.

An interesting development is that a consensus is being built on the factors that facilitate as well as impede the development of high-performance work organisations in Africa. Undoubtedly, management research on institutions and HPOs have benefited from increased focus on Eastern Europe, Central Europe and Asia, with norms, rules and contexts different from that of the western developed economies [1]. By extension, management research will benefit from our extension of institutional and HPOs research to the frontiers of Africa, where the context, norms and rules are quite different from those in Asia, Central and Eastern Europe as well as the West. Of course, the HPWPs perspective which emphasises the creation of 
Accepted Manuscript.

Book chapter (https://doi.org/10.1007/978-3-030-13229-3_9) published in Management Science:

Foundations and Innovations (https://doi.org/10.1007/978-3-030-13229-3), Springer International

Publishing, 2 March 2019

sustained competitive advantage through active employee participation in workplace decisions and the utilisation of their knowledge, skills, abilities and other characteristics in ways beneficial to the organisation where they work can be expanded in Africa. Essentially, an understanding of how firms operating in SSA can leverage on HPWPs to create HPWOs will greatly enrich the development of HPWP perspective and enhance its global status.

\section{Practical implication of the study}

This paper has some practical implications for managers operating within the emerging markets of SSA. First, the discussions in this paper provide huge and nuanced insights for managers on what and how institutional factors facilitate and also impede the creation of highperformance work organisations in SSA. We argue that such awareness will enable managers to think proactively on how to develop the relevant capabilities and resources required in addressing the constraints linked with this institutional environment. Second, practising managers within the SSA region can also acquire knowledge about how to facilitate the development of high-performance work organisation in partnership with governments in Africa without encountering much resistance from employees and union representatives. Earlier studies suggest that the implementation of HPWPs (i.e. those with adverse effect on employee wellbeing) may sometimes be frustrated by union activities in societies where they are recognised by law [13]. Moreover, some managers in a collectivist environment like SSA may also be reluctant to apply HPWPs with negative outcomes for employees' wellbeing. Finally, the study offers a lot of insights for SSA governments on how legislation's impact the development of high-performance organisations and how they can partner with the private sector to develop the workforce relevant for creating HPWOs. Admittedly, organisations that can leverage on high-performance work practices in ways that enable them to overcome the 
Accepted Manuscript.

Book chapter (https://doi.org/10.1007/978-3-030-13229-3_9) published in Management Science:

Foundations and Innovations (https://doi.org/10.1007/978-3-030-13229-3), Springer International

Publishing, 2 March 2019

challenges associated with the complex and unpredictable institutional environment in SSA are more likely to achieve HPO status.

\section{Limitations and directions for future research}

This research has a few limitations which can be addressed by future research. The first limitation is that we have focused on theory expansion without providing any empirical evidence to support our claims. We suggest that future empirical work should test the arguments presented in this study. The second limitation is that the authors tend to focus on institutional and HPWPs theories in understanding the factors that facilitate as well as impede the development of HPOs in SSA and how organisations in the region can adopt HPWPs to advance their HPO status. We assert that both theories are only a starting point and not exhaustive, thus, future research should explore other theories to stimulate scholarly discourse on developing management theories relevant to SSA organisations. Finally, we only studied the sub-Saharan Africa region in Africa. We suggest that similar studies should be conducted in the other regional block in order to develop a more holistic theory for Africa. There is a growing consensus that the institutional environment of the emerging markets of Africa appears to be a very fertile ground to test and expand existing institutional theories as well as develop new ones [67].

\section{Conclusion}

This study has enhanced our understanding of institutional factors that facilitate but also impede the development of high-performance organisations in SSA. The study shed light on how organisations in SSA can leverage on HPWPs to improve their HPOs status. A bulk of the literature on institutions is from the developed western contexts. More recently, a number of studies have emerged from the emerging contexts of Asia and Eastern and Central Europe. 
Accepted Manuscript.

Book chapter (https://doi.org/10.1007/978-3-030-13229-3_9) published in Management Science:

Foundations and Innovations (https://doi.org/10.1007/978-3-030-13229-3), Springer International

Publishing, 2 March 2019

Admittedly, only a handful of institutional literature is from the emerging context of Africa where there a distinct norms and rules. However, this study provides very strong and nuanced evidence that regulatory, normative and socio-cultural institutional factors impede but also facilitate the creation of HPOs in SSA.

The crucial lesson that emerged from the study is that organisations operating within the SSA region can adopt high-performance work practices to improve their HPO status. HPO status is moderated by strong human capital base and positive employee attitude. For successful implementation of HPWP, SSA firms must embrace the AMO human resource structure to avoid any form of resistance to the adoption of HPWPs in a highly collectivist context like the SSA. The government can also support this move by facilitating the adoption of HPWPs both directly and indirectly for the overall development of the relevant workforce needed for the creation of HPWOs.

\section{References}

1. Zoogah, D.B., Peng, M.W. and Woldu, H. (2015). "Institutions, resources and organizational effectiveness in Africa", The Academy of Management Perspectives. Vol. 29, pp. 7-31.

2. George, G., Corbishley, C. Khayesi, J.N.O., Haas, M.R. and Tihanyi (2016). From the editors: bringing Africa in: promising directions for management research. Academy of Management Journal, Vol. 59, pp. 377-393.

3. de Waal, A.A., Goedegebuure, \& Mulimbika, (2014). Creating high performance governmental organizations in Zambia. African Journal of Business and Economic Research. Vol. 9, pp. 57-86.

4. Aiginger, K. (2009). 'Strengthening the resilience of an economy'. Intereconomics, Vol. 44, pp. 309-316.

5. Peng, M. W. (2014). Global business (3rd ed.). Cincinnati: Cengage Learning.

6. Ogbonnaya, C., Daniels, K., Connolly, S., van Veldhoven, J.P.M. and Nielsen, K. (2016). Employees, managers and high-performance work practices, in Ashkanasy, N.M., Bernett, R.J. AND Martinko, M.J. (Eds.) understanding the high-performance workplace: the line between motivation and abuse, New York, Routledge 
Accepted Manuscript.

Book chapter (https://doi.org/10.1007/978-3-030-13229-3_9) published in Management Science:

Foundations and Innovations (https://doi.org/10.1007/978-3-030-13229-3), Springer International

Publishing, 2 March 2019

7. Kashefi, M. (2011). High-performance work organizations and rewards in manufacturing and services economies. International Sociology, Vol. 26, pp. 547-570.

8. Godard J (2001). High performance and the transformation of work? The implications of alternative work practices for the experience and outcomes of work. Industrial and Labor Reviews Vol. 54, pp. 776-805.

9. O'Reilly, C.A. and Pfeffer, J. (2000). Hidden value. How great companies achieve extraordinary results with ordinary people. Harvard Business School Press, Boston.

10. Miller, D. and Le Breton-Miller, I. (2005). Managing for the long run. Lessons in competitive advantage from great family businesses. Harvard Business School Press, Boston.

11. de Waal, A.A. (2001). Power of performance management. How leading companies create sustained value. John Wiley \& Sons, New York.

12. de Waal, A.A. (2006). The Characteristics of a High Performance Organisation (Online): Available at $\quad$ SSRN: https://ssrn.com/abstract=931873 or http://dx.doi.org/10.2139/ssrn.931873 (accessed: 31-05-2017).

13. Lawler J., Chen, S.,Wu, P-C., Bae, J., and Bai, B. (2008). High performance work system practices in foreign subsidiaries of American multinationals: A multi-country study. Unpublished paper, 1-12.

14. Whitener, E. (2001), "Do high commitment human resource practices affect employee commitment? A cross-level analysis using hierarchical linear modelling". Journal of Management, Vol. 27, pp. 515-35.

15. Gould-Williams, J. (2003). The importance of HR practices and workplace trust in achieving superior performance: a study of public-sector organizations. The International Journal of Human Resource Management, Vol. 14, pp. 28-54.

16. Ashton, D. N. and Sung, J. (2002). Supporting workplace learning for high performance working. International Labour Organization.

17. Dunning, J. H., \& Lundan, S. M. (2008). Institutions and the OLI paradigm of the multinational enterprise. Asia Pacific Journal of Management, Vol. 25, pp. 573-593.

18. Ingram, P., \& Silverman, B. (2002). Introduction in the new institutionalism in strategic management. In P. Ingram \& B. Silverman (Eds.), The new institutionalism in strategic management. Amsterdam: Elsevier.

19. North, D. C. (1990). Institutions, institutional change, and economic performance. New York: Cambridge University Press.

20. Scott, W.R. (1995). Institutions and organizations. Thousand Oaks, CA: Sage.

21. Kostova, T. (1999). Transnational transfer of strategic organizational practices: A contextual perspective. Academy of Management Review, Vol. 24: pp. 308-324. 
Accepted Manuscript.

Book chapter (https://doi.org/10.1007/978-3-030-13229-3_9) published in Management Science:

Foundations and Innovations (https://doi.org/10.1007/978-3-030-13229-3), Springer International

Publishing, 2 March 2019

22. Westney, D.E. (1993). "Institutionalization theory and the multinational corporation", in Ghoshal, S. and Westney, D.E. (Eds), Organization Theory and the Multinational Corporation, St. Martin's Press, New York, NY.

23. Scott, R. W. and Meyer, J.W. (1983). Organizational Environments: Ritual and Rationality, Sage, Beverly Hills, CA.

24. Rottig, D. (2016). "Institutions and emerging markets: effects and implications for multinational corporations". International Journal of Emerging Markets, Vol. 11, pp.2-17.

25. Scott, W.R. (2014). Institutions and Organizations: Ideas, Interests and Identities, (4th ed.). SAGE Publications, Thousand Oaks, CA.

26. Urban, B. and Hwindingwi, R. (2016). "The influence of institutional factors on MNC's triple bottom-line reporting: A focus on African emerging markets (AEMs)". International Journal of Emerging Markets, Vol. 11, pp.497-513.

27. Puffer, S.M., McCarthy, D.J and Jaeger, A.,M. (2016). "Institution building and institutional voids: Can Poland's experience inform Russia and Brazil?". International Journal of Emerging Markets, Vol. 11, pp.18-41

28. Rousseau, D.M. and Fried, Y. (2001). 'Location, location, location: contextualizing organizational research'. Journal of Organizational Behavior, Vol. 22, pp. 1-13.

29. Johns, G. (2006). The essential impact of context on organizational behavior. Academy of Management Review, Vol. 31, pp. 386-408.

30. Beugré, C. D., \& Offodile, O. F. (2001). Managing for organizational effectiveness in subSaharan Africa: A culture-fit model. International Journal of Human Resource Management, Vol. 12, pp. 535-550.

31. Adams, K., Debrah, Y. A., Williams, K. and Mmieh, F. (2015). Why on Earth Should Foreign Banks Invest in Africa's Financial Services Sector? Evidence from Financial Multinationals in Ghana. Thunderbird International Business Review, 57, pp. 445-462.

32. Ovadge, F. and Ankomah, A. (2004). Human resource management in Nigeria, in Budhwar, P.S. and Debrah, Y.A (eds.) human resource management in developing countries: London, Routledge Publishers.

33. Jin, Y., Hopkins, M. M., and Wittmer, J. L. S. (2010). Linking Human Capital to Competitive Advantages: Flexibility in a Manufacturing Firm's Supply Chain. Human Resource Management, Vol. 49, pp. 939-963.

34. Debrah, Y. A., Oseghale, R. O. and Adams, K. (2017). Human capital development, innovation and international competitiveness in Sub-Saharan Africa. In I. Adeleye and M. Esposito (eds.) Africa's competitiveness in the global economy. London: Palgrave Macmillan.

35. Rivera-Santos, M., Holt, D., Littlewood, D., \& Kolk, A. (2015). Social entrepreneurship in sub-Saharan Africa. Academy of Management Perspectives, Vol. 29. PP. 1-49.

36. Hyden, G. (2006). African politics in comparative perspective. Cambridge, UK: Cambridge University Press. 
Accepted Manuscript.

Book chapter (https://doi.org/10.1007/978-3-030-13229-3_9) published in Management Science:

Foundations and Innovations (https://doi.org/10.1007/978-3-030-13229-3), Springer International

Publishing, 2 March 2019

37. Sidani, Y.M. and Thornberry, J. (2013). Nepotism in the Arab world: an institutional theory perspective. Business Ethics Quarterly, Vol. 23, pp. 69-96.

38. Bamett, T., \& Kellermanns, E. W. (2006). Are we family and are we treated as family? Nonfamilyemployees' perceptions of justice in the family firm. Entrepreneurship Theory and Practice, Vol. 30, pp 837-54.

39. Oppong, N.Y. and Gold, J. (2016). "Developing local managers in the Ghanaian mining industry: an indigenous talent model". Journal of Management Development, Vol. 35: 3, pp. 341-359.

40. Mangaliso, M. P. (2001). Building competitive advantage from Ubuntu: Management lessons from South Africa. Academy of Management Executive, Vol. 15, pp. 23-33.

41. Mensah, F. and Oppong, N. (2016). Improving employee performance at Kakum rural bank limited, Ghana: role of motivational packages. International Journal of Management and Applied Science, Vol. 2, pp. 68-75.

42. Aryeetey, E., \& Killick, J. (2000). Aid debt and growth in the Ghanaian economymacroeconomic and sectoral developments since 1970. In E. Aryeetey, J. Harrigan, \& M. Nissanke (Eds.), Economic reforms in Ghana: The miracle and the mirage. Oxford, England: Woeli.

43. Mbaku, J. M. (2004). Institutions and development in Africa. Trenton, NJ: Africa World Press, Inc.

44. Sidani, Y.M. and Al Ariss, A. (2014). Institutional and corporate drivers of global talent management: evidence from the Arab Gulf region. Journal of World Business, Vol. 49, pp. 215-224.

45. Harry, W. (2007). "Employment creation and localization: the crucial human resource issues for the GCC". The International Journal of Human Resource Management, Vol. 18, pp. 132-146.

46. Al Qudsi, S.S. (2006). Unemployment Evolution in the GCC Economies: Its Nature and Relationship to Output Gaps, Center for Market Research \& Information (CLMRI), Abu Dhabi.

47. Oseghale, O. R. (2016). Talent management in multinational companies in the Nigeria oil and gas industry. Unpublished doctoral thesis.

48. Adisa, T, A., Osabutey, E. L.C., Gbadamosi, G. and Mordi, C. (2017) "The challenges of employee resourcing: the perceptions of managers in Nigeria". Career Development International, Vol. 22, pp.703-723.

49. Nwogwugwu, N. and Sosanya, O.A. (2015). Effects of federal character on appointment into the civil service system: a study of federal ministry of education. Arabian Journal of Business and Management Review, Vol. 3, pp. 1-12.

50. Zhou, J. Q., \& Peng, M. W. (2012). Does bribery help or hurt firm growth around the world? Asia Pacific Journal of Management, Vol. 29, pp. 907-921. 
Accepted Manuscript.

Book chapter (https://doi.org/10.1007/978-3-030-13229-3_9) published in Management Science:

Foundations and Innovations (https://doi.org/10.1007/978-3-030-13229-3), Springer International

Publishing, 2 March 2019

51. Acquaah, M. (2007). Managerial social capital, strategic orientation, and organizational performance in an emerging economy. Strategic Management Journal, 28, pp. 1235-1255.

52. Michalopoulos, S., \& Papaioannou, E. (2015). On the ethnic origins of African development: Chiefs and precolonial political centralization. The Academy of Management Perspectives, Vol. 29, pp. 37-71.

53. Chironga, M., Leke, A., Lund, S., \& Van Wamelen, A. (2011). Cracking the next growth market: Africa. Harvard Business Review, Vol. 89, pp. 117-122.

54. Collier, P. (2007). The bottom billion: Why the poorest countries are failing and what can be done about it. Oxford, UK: Oxford University Press.

55. Ugwegbu, D. C. E. (2001). The psychology of management in African organizations. Westport, CT: Quorum.

56. Dia, M. (1996). Africa's management in the 1990s and beyond. Washington, DC: World Bank.

57. Yeung, H. W. (2000). Limits to the growth of family-owned business? The case of Chinese transnational corporations from Hong Kong. Family Business Review, Vol. 13: pp. 55-70.

58. Khanna, T. and Palepu, K. (2005). "Spotting institutional voids in emerging markets", Harvard Business School Background Note 106-014, August, pp. 1-11.

59. Amankwah-Amoah, J. (2016). An integrative process model of organisational failure. Journal of Business Research, Vol. 69, pp. 3388-3397.

60. Jiang, K., Lepak, D., \& Baer, J. (2012). How does human resource management influence organizational outcomes? A meta-analytic investigation of mediating mechanisms. Academy of Management Journal, Vol. 55, pp. 1264-1294.

61. Sun, L., Aryee, S., \& Law, K. (2007). High-performance human resource practices, citizenship behavior, and organizational performance: A relational perspective. Academy of Management Journal, Vol. 50, 558-577.

62. Ogbonnaya, C., Daniels, K., Van Veldhoven, M., \& Tregaskis, O. (2013). Using HPWP to drive towards growth: The impact of occupational health and safety leadership. In: G. Saridakis \& C. Cooper (Eds), How HR can drive growth. Cheltenham: Edward Elgar Publishing.

63. Huselid, M. A. (1995). The impact of human resource management practices on turnover, productivity, and corporate financial performance. Academy of Management Journal, Vol. 38: 635-672.

64. Gong, Y., Law, K., Chang, S., \& Xin, K. (2009). Human resources management and firm performance: The differential role of managerial affective and continuance commitment. Journal of Applied Psychology, Vol. 94, 263-275.

65. Applebaum, E.; Bailey, T.; Berg, P.; Kalleberg, A.L. (2000). Manufacturing advantage: Why high performance work systems pay off, London, Cornell University Press. 
Accepted Manuscript.

Book chapter (https://doi.org/10.1007/978-3-030-13229-3_9) published in Management Science:

Foundations and Innovations (https://doi.org/10.1007/978-3-030-13229-3), Springer International

Publishing, 2 March 2019

66. Farrell, D. and Grant, A. (2005). China's looming talent shortage, The McKinsey Quarterly, Vol. 4, pp. 71-79.

67. Zoogah, D. B. (2008). African business research: A review of studies published in the Journal of African Business and a framework for enhancing future studies. Journal of African Business, Vol. 9, pp. 219-255. 